\title{
GRAIN BOUNDARY OXIDATION AND THE CHROMIUM- DEPLETION THEORY OF INTERCRYSTALLINE CORROSION OF AUSTENITIC STAINLESS STEELS
}

\author{
P. J. Gellings and M. A. DE JONGH \\ Technische Hogeschool Twente, Enschede, Netherlands
}

\begin{abstract}
High temperature microscopy during oxidation of austenitic stainless steels shows that an increased rate of oxidation is found in a narrow zone along grain boundaries where chromium carbides have been precipitated. This lends support to the chromium-depletion theory of intercrystalline corrosion of these steels. Approximate solution of the appropriate diffusion problem shows good agreement with the experimental results.
\end{abstract}

Résumé-L'examen au microscope et à haute température du comportement d'aciers inoxydables austénitiques révèle une vitesse d'oxydation accrue dans une zone étroile, le long des limites de grains où les carbures de chrome ont été précipités. Ceci corrobore la théorie de la corrosion intercristalline de ces aciers par appauvrissement en brome. Les résultants expérimentaux concordent de manière satisfaisante avec solution approchée du problème de diffusion.

Zusammenfassung-Mit einem Hochtemperaturmikroskop konnte festgestellt werden, da B die Oxydation von austenitischen Stählen in einer engen Zone in der Umgebung der Korngrenzen mit erhöhter Geschwindigkeit verläuft, wenn auf den Korngrenzen Chromkarbide ausgeschieden sind. Dieser Befund stützt die Chromverarmungstheorie der interkristallinen Korrosion dieser Legierungen. Näherungslösungen der Diffusionsgleichung ergaben gute Übereinstimmung mit den experimentellen Ergebnissen.

Реферат - С помощью высокотемпературного микроскопа при окислении аустенитных нержавеющих сталей показано, что повышенная скорость окисления ойнаруживается в узкой зоне вдоль граєицы зерен, где осаждаютяя карбиды хрома. Можно предположить, что межкристаллитная коррозия әтих сталей происходпт по теории истощения хрома. Приближенное решение соответствуюей диффузионной проблемы хорошо согласуется әкспериментальными данными.

\section{INTRODUCTION}

SEVERAL theories have been proposed to account for intercrystalline corrosion of chromium-nickel stainless steels. ${ }^{1}$ In this paper arguments are put forward, based upon high-temperature microscopy, strengthening the case for the so-called chromiumdepletion theory. It is shown here that this high-temperature method differentiates more easily between the several theories than the usual methods in which the phenomena are studied in an electrolyte solution.

*Manuscript received April 1966. 


\section{Basic phenomena ${ }^{2}$}

The general conclusions reached with respect to intercrystalline corrosion of the chromium-nickel austenitic stainless steels can be summarized as follows:

(i) In several media (e.g. $\mathrm{HNO}_{3}, \mathrm{H}_{2} \mathrm{SO}_{4}$, etc.) these steels show a selective attack along the grain boundaries leading to disintegration of the metal after heat treatment in the region $500-850^{\circ} \mathrm{C}$.

(ii) After this heat treatment microscopic investigation shows a continuous network of chromium carbides along the grain boundaries.

(iii) Heat treatment at about $1050^{\circ} \mathrm{C}$ followed by rapid quenching destroys the sensitjvity to intercrystalline corrosion and microscopic examination shows that all carbides have then gone into solution.

(iv) Alloying with titanium or niobium leads to the formation of very stable titanium- or niobium-carbides dispersed throughout in the steel; these stabilized steels are insensitive to heat treatment in the above-mentioned region of $500-850^{\circ} \mathrm{C}$.

(v) Finally, at lower carbon contents the sensitivity is in general lower under otherwise identical circumstances.

Theories

Of the several theories proposed to explain these phenomena the two main ones are:

(a) chromium-depletion theory;

(b) electrochemical theory.

For a more extensive account of these theories see ref. (1).

(a) Chromium-depletion theory. A chromium-nickel austenitic stainless steel quenched in water after heat treatment at $1050-1100^{\circ} \mathrm{C}$ is a supersaturated solution of carbon in the $\mathrm{Fe}-\mathrm{Cr}-\mathrm{Ni}$-austenitic mixed crystal. Annealing at temperaiures of about $500-850^{\circ} \mathrm{C}$ or cooling slowly after heating to higher temperatures lead to the precipitation of carbides. This takes place mainly at the grain boundaries, particularly at the lower temperatures.

Because of this local precipitation the chromium and carbon have to be transported to the grain boundary by diffusion. The diffusion coefficient of carbon is much larger (by a factor of about $10^{4}$ ) than that of chromium. ${ }^{3-5}$ This is related to the fact that carbon is present interstitially, chromium substitutionally. As a consequence the concentration of chromium in the neighbourhood of the grain boundary after precipitation of the chromium carbides (of composition $\mathrm{Cr}_{23} \mathrm{C}_{6}$ ) is decreased below that in the bulk of the crystallites.

Now the corrosion resistance of these steels is due to their passivity for which, under average conditions, a minimum chromium-content of about $15 \%$ is necessary. ${ }^{2}$ In the region adjacent to the grain boundary after carbide precipitation, the concentration may be decreased below this value. This then leads to a destruction of the passivity of these zones and hence to intercrystalline corrosion.

(b) Electrochemical theory. The precipitation of chromium carbides is again supposed to be the primary cause of the intercrystalline corrosion but, as pointed out by Stickler and Vinckler, ${ }^{6,7}$ these carbides are more noble than the metal itself and are electronic conductors. This causes galvanic action in which the carbides are the local 
cathodes and the metal is the anode. Due to the small surface area of the carbides the attack is limited to a narrow zone directly adjacent to the grain boundaries.

It is clear that a differentiation between these mechanisms by means of experiments in an electrolyte solution is not possible. Several authors have investigated the composition of the electrolyte after intercrystalline corrosion and have found a decreased chromium content of the solution compared to the mctal. ${ }^{8,9}$ Investigation of fractured surfaces of stainless steels with carbide precipitates also gave indications of a decreased chromium content. ${ }^{10}$

The chromium-depletion theory, however, predicts that the oxidation rate at high temperatures will also be greater along the grain boundaries due to the precipitation of chromium carbide which thus lowers the $\mathrm{Cr}$ content of the alloy at these areas. Figure 1 shows how the rate of oxidation ${ }^{11,12}$ increases with decreasing chromiumcontent.

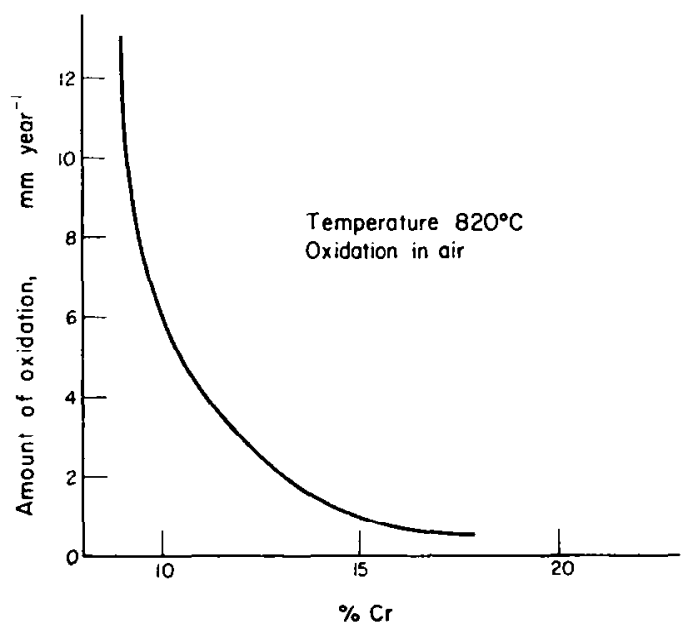

FIG. 1. Rate of oxidation of $\mathrm{Fe}-\mathrm{Cr}$-alloys as a function of $\mathrm{Cr}$-content.

Observation of the oxidation of stainless steel in which chromium carbides have been precipitated makes it possible to make a choice between these two theories, since the electrochemical theory does not predict an increased oxidation rate along the grain boundaries.

\section{EXPERIMENTAL}

\section{Apparatus}

All experiments were performed by means of the Vacutherm vacuum heating chamber mounted on a Melabor microscope ${ }^{13}$ (C. Reichert, Vienna). The specimen was heated in a high vacuum and viewed through a quartz window. The temperature of the specimen was measured by means of a thermocouple inserted in a small hole close to the surface under investigation. The heating chamber could be evacuated to $10^{-5}$ Torr and if necessary gases could be admitted during heating.

The heating chamber was flushed with argon beforc evacuation. The argon was of type $\mathrm{N} 48$ with as maximum amounts of impurities: $\mathrm{H}_{2} \mathrm{O} 5 \mathrm{ppm}, \mathrm{N}_{2} 10 \mathrm{ppm}, \mathrm{O}_{2} 1 \mathrm{ppm}$. 


\section{Materials}

Table 1 gives the compositions of the four types of austenitic stainless steel used in this investigation.

Table 1, Percent compostrion of alloys

\begin{tabular}{lcccc}
\hline & AISI & AISI & AISI & AISI \\
& 304 & 347 & 321 & 316 \\
\hline $\mathrm{C}$ & 0.042 & 0.035 & 0.048 & 0.049 \\
$\mathrm{Cr}$ & $17 \cdot 7$ & $18 \cdot 3$ & $18 \cdot 1$ & $18 \cdot 6$ \\
$\mathrm{Ni}$ & $9 \cdot 3$ & $9 \cdot 6$ & $9 \cdot 2$ & $9 \cdot 7$ \\
$\mathrm{Mo}$ & - & - & - & 1.85 \\
$\mathrm{Nb}$ & - & 0.22 & - & - \\
$\mathrm{Ti}$ & - & - & 0.26 & - \\
\hline
\end{tabular}

The following heat treatments were used:

(a) as received.

(b) as (a), followed by $20 \mathrm{~h}$ at $650^{\circ} \mathrm{C}$.

(c) $2 \mathrm{~h}$ at $1050^{\circ} \mathrm{C}$, quenched in water.

(d) as (c), followed by $20 \mathrm{~h}$ at $650^{\circ} \mathrm{C}$.

(e) as (c), followed by $1 \mathrm{~h}$ between $850-900^{\circ} \mathrm{C}$.

(f) as (e), followed by $20 \mathrm{~h}$ at $650^{\circ} \mathrm{C}$.

With regard to these heat treatments the following comments can be made:

$\mathrm{b}, \mathrm{d}, \mathrm{f}$-annealing at $650^{\circ} \mathrm{C}$ caused maximum precipitation of chromium carbides on the grain boundaries.

$\mathrm{c}, \mathrm{d}, \mathrm{e}, \mathrm{f}$-heating at $1050^{\circ} \mathrm{C}$ causes dissolution of all carbides and quenching in water gave a rate of cooling fast enough to hold all carbon in supersaturated solution.

e, f-the stabilized materials ( 347 and 321 ) were subjected to a stabilizing heat treatment between $850-900^{\circ} \mathrm{C}$ to give optimum conditions for precipitation of titanium or niobium carbides.

After heat treatment the specimens were ground wet on carborundum paper (grades 320-400-600) and polished with $7 \mu$ diamond paste. They were then polished successively with $0.3 \mu$ and $0.05 \mu$ aluminium oxide. This was followed by final polishing with clean water.

The thermal etching was performed in the Vacutherm at the temperature of investigation $\left(650^{\circ} \mathrm{C}\right)$. Due to the extreme sensitivity to slight surface imperfections (scratches and even the deformed zone ${ }^{14}$ under former scratches) the finest grade of $\mathrm{Al}_{2} \mathrm{O}_{3}$ had to be used. Furthermore it is necessary to remove all $\mathrm{Al}_{2} \mathrm{O}_{3}$ which may be embedded in soft spots and particularly on grain boundaries as otherwise enhanced oxidation may result. ${ }^{15}$ This was the reason for the final polishing with water alone.

\section{Oxidation}

The traces of $\mathrm{H}_{2} \mathrm{O}$ and $\mathrm{O}_{2}$ present in the argon and leaking into the heating chamber were sufficient to cause a high enough rate of oxidation in most cases if the pressure was kept between about $3+10^{-5}$ and $10^{-4}$ Torr. At higher pressures the oxidation was 


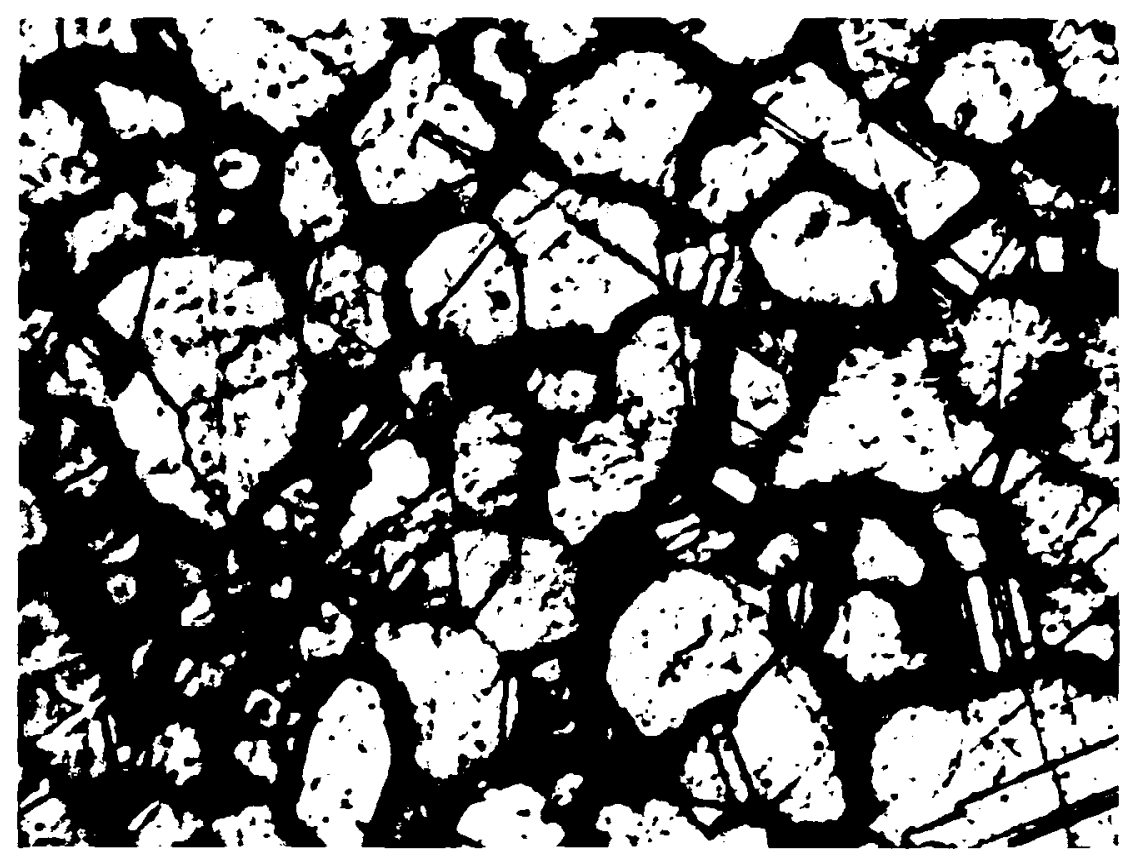

FIG. 2. A.I.S.L. type 304 after $20 \mathrm{~min}$ at $650^{\circ} \mathrm{C}$. Magnification 300.

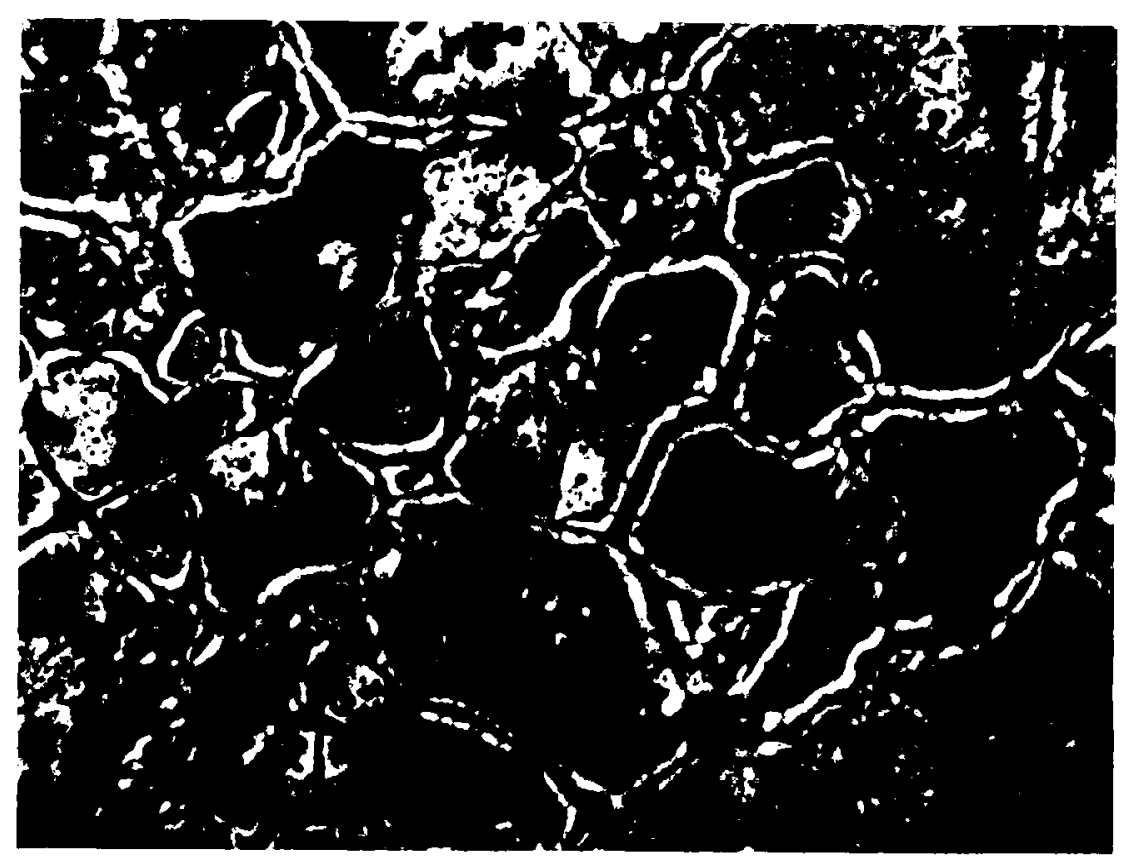

Fig. 3. A.I.S.I. type 304 , heat treatment d, photographed after $60 \mathrm{~min}$ at $650 \mathrm{C}$. Magnification $\% 300$. 


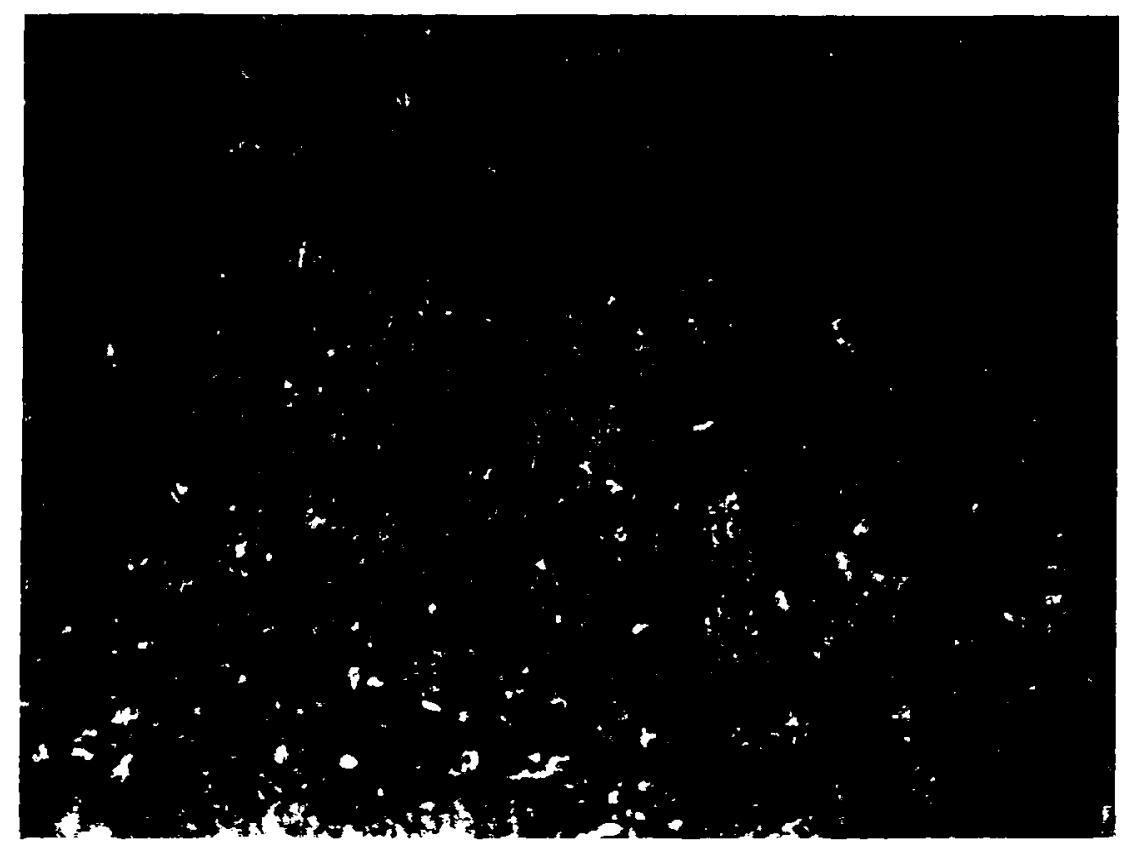

FIG. 4. A.I.S.I. type 321 , heat treatment e, photographed after 20 min at $650^{\circ} \mathrm{C}$. Magnification $\times 300$.

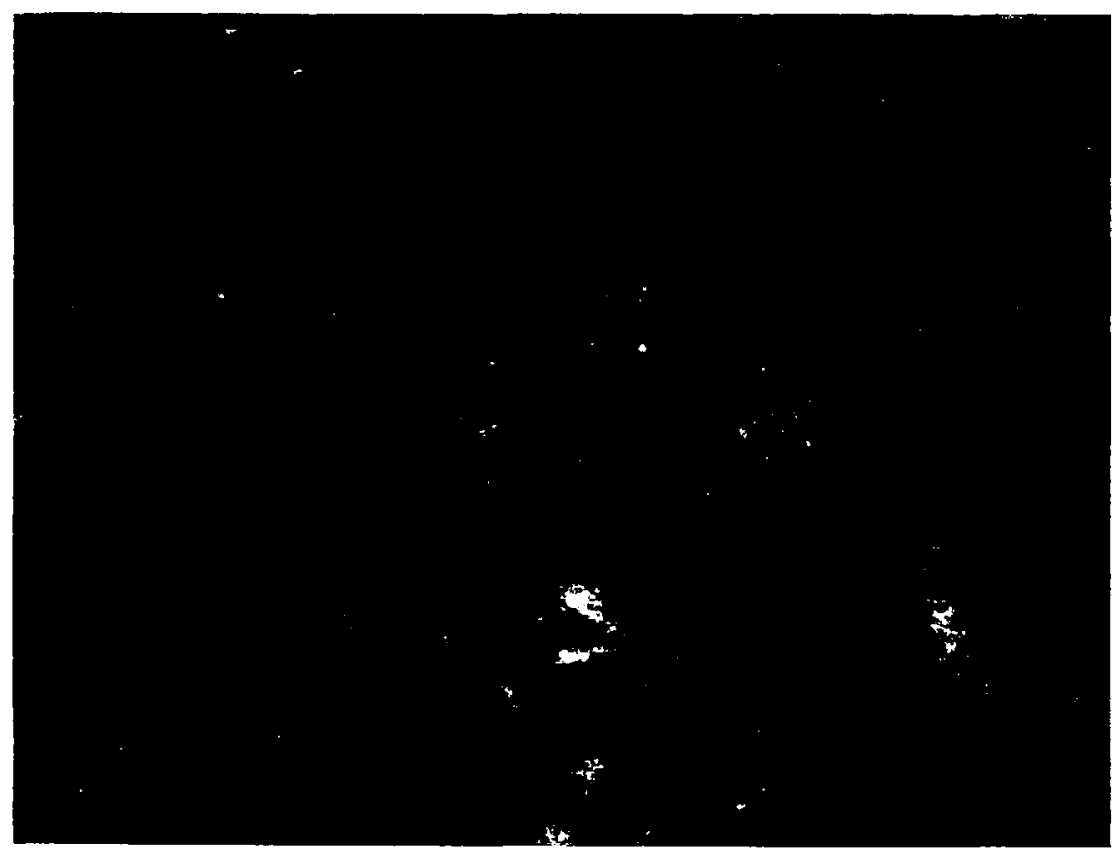

FIG. 5. A.I.S.I. type 321 , heat treatment f, photographed after $20 \mathrm{~min}$ at $650^{\circ} \mathrm{C}$. Magnification $\times 300$. 


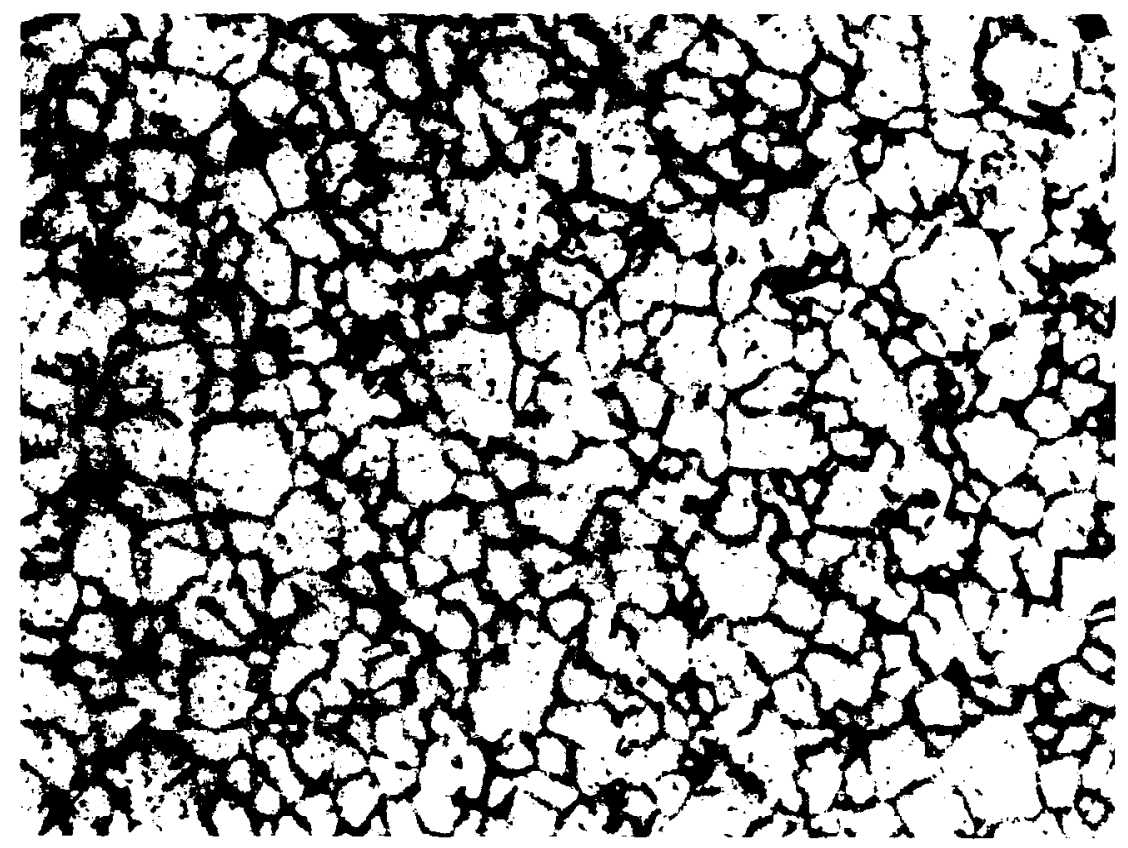

FIG. 6. A.I.S.I. type 347 , heat treatment a, photographed after $10 \mathrm{~min}$ at $650 \mathrm{C}$. Magnification $\therefore 300$.

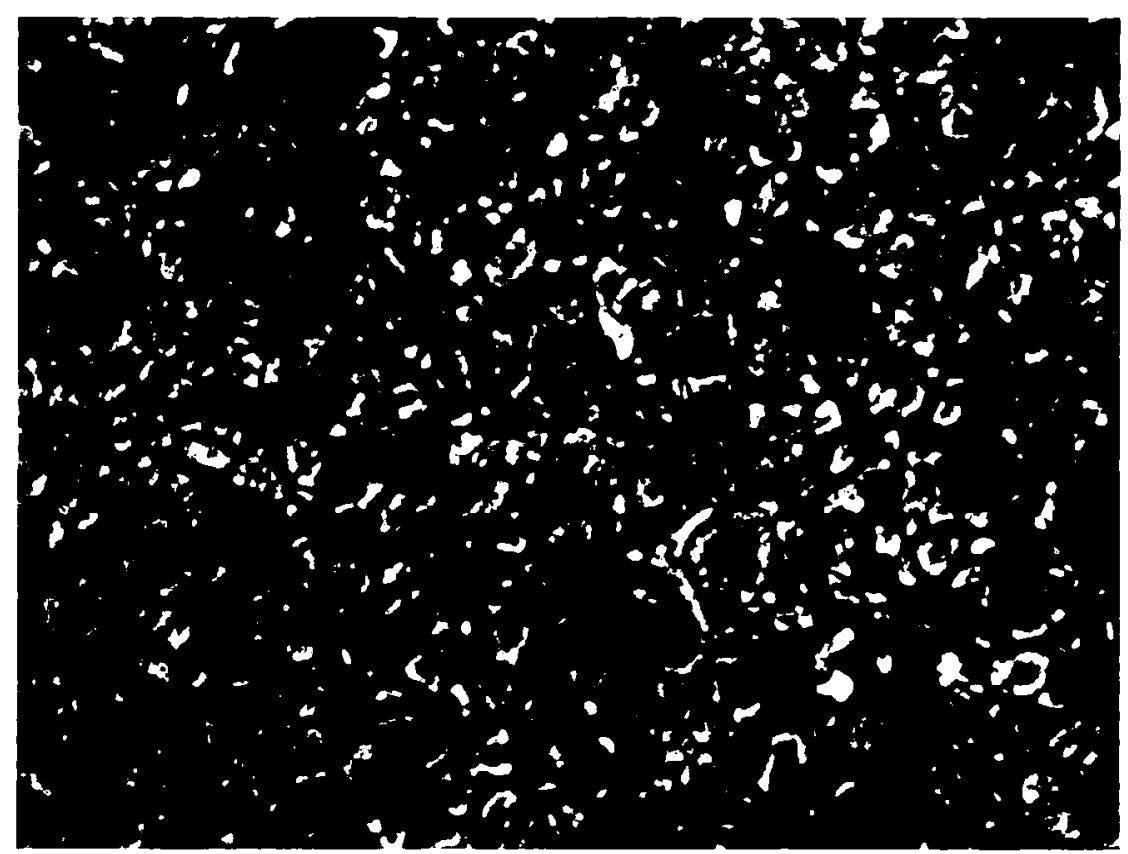

FIG. 7. A.I.S.I. type 347, heat treatment a, photographed after $40 \mathrm{~min}$ at $650^{\circ} \mathrm{C}$. Magnification $\times 300$. 
too fast, but in some cases where the oxidation was very slow the pressure was raised above $10^{-4}$ Torr for a short time.

After reaching the desired vacuum at the start of an experiment the temperature was raised as quickly as possible while maintaining the vacuum. The thermal etching at $650^{\circ} \mathrm{C}$ took approximately $2-3 \mathrm{~min}$.

\section{RESULTS}

It is well known that the colour changes during the thickening of the oxide layer (interference films) can be used to determine the thickness of the oxide. ${ }^{11,16}$ These colour changes occur in the order: yellow-brown-blue-grey-yellow (second order) which correspond to thicknesses of about $460-600-720-820-920 \AA$.

By observing the colour changes on different specimens it was possible to distinguish three different types of oxidation behaviour.

I. Grain boundary oxidation. In this case the grain boundary and its direct surroundings show the thickest oxide layer from the commencement of oxidation. After 5 min they are visible as sharp black lines with a dark brown border on both sides of width approximately $2 \times 2 \mu$. After 10 min these borders become blue and somewhat wider while the grain boundary proper remains visible as a black line in the centre. After about 25 min the grains themselves start to change their brown colour into blue, beginning from the grain boundary. Simultaneously the grain boundary changes its colours from grey to second order yellow. Two stages in this oxidation are shown in Figs. 2 and 3.

II. General surface oxidation. Here the whole surface shows a discoloration and the grain boundaries are only visible as lines of demarcation between the differently coloured grains (Figs. 4 and 5) which oxidize at somewhat different rates due to their difference in orientation. ${ }^{17}$ The general change in colour is from brown to blue and grey to second order yellow after about $25 \mathrm{~min}$. In most cases the oxidation was slow in starting and the pressure had to be raised to initiate the oxidation.

III. Intermediate oxidation. In this case the oxidation starts at the grain boundaries and scratches, but spreads rather quickly over the whole surface. After about $15 \mathrm{~min}$ the grain boundaries have disappeared altogether as is shown in Figs. 6 and 7.

In Table 2 the observations on the different materials after heat treatment have been summarized.

TABle 2. Observations on OXIDATION behaviour

\begin{tabular}{|c|c|c|c|c|}
\hline \multirow[b]{2}{*}{ Heat treatment } & \multicolumn{4}{|c|}{ Alloy } \\
\hline & $\begin{array}{c}\text { AISI } \\
304\end{array}$ & $\begin{array}{c}\text { AISI } \\
347\end{array}$ & $\begin{array}{c}\text { AISI } \\
321\end{array}$ & $\begin{array}{c}\text { AISI } \\
316\end{array}$ \\
\hline $\mathbf{a}$ & I & III(II) & II & - \\
\hline $\mathrm{b}$ & I & II & II & - \\
\hline c & $\mathrm{II} \rightarrow \mathrm{I}$ & II & - & II \\
\hline $\mathrm{d}$ & I & II & II(IU) & I \\
\hline e & - & III & II(III) & - \\
\hline f & - & II & II & 一 \\
\hline
\end{tabular}




\section{DISCUSSION}

It is clear that for the unstabilized steel type A.I.S.I. 304 grain boundary oxidation takes place in accordance with what is to be expected according to the chromiumdepletion theory. When it has been solution-heat treated (Table 2, c) oxidation proceeds all over the surface (but only after the pressure has been raised), but after some time blue borders appear at the grain boundaries. This is obviously connected with the fact that the oxidation temperature is also the temperature where carbide precipitation occurs.

The unstabilized steel (type 316) also shows grain boundary oxidation after carbide precipitation but in the solution-heat treated condition general oxidation occurs.

In the majority of cases type 347 shows general oxidation in accord with expectations. In some cases the intermediate type of oxidation occurs. The comparison with the other materials was made difficult, however, by the fact that it was much more finegrained (Fig. 6). A large number of grain boundaries become blue at practically the same moment and the colour spreads very quickly over the small crystallites. This behaviour differs markedly from all other observations.

Type 321 shows general oxidation in all cases. Only before the final polishing with water was used was the intermediate oxidation observed in two cases. This was presumably due to aluminium-oxide embedded in the grain boundaries after polishing.

All these observations support qualitatively the chromium-depletion theory: in those cases where chromium carbides have been precipitated grain boundary oxidation occurs, whereas when no chromium carbides are precipitated there is general oxidation. As was stated above, this is to be expected when chromium depletion occurs.

The measurements show that after about 7 min the width of the oxidized zone is approximately $2 \mu$ and in the Appendix a derivation is given for the width of the depleted zone (which is of course not sharply defined). This calculation gives $1.67 \mu$ for the width which is in good accord with the experimental result.

\section{SUMMARY AND CONCLUSION}

The microscopic investigation reported in this paper shows that austenitic stainless steel, in which chromium carbides have been precipitated along the grain boundaries, is oxidized preferentially along the grain boundaries, and this observation, which cannot be explained by the electrochemical theory, gives support to the chromiumdepletion theory of intercrystalline corrosion.

\section{REFERENCES}

1. A. Bäumel, H. E. Bühler, H. J. Schüller, P. SchwaAB, T. Ternes and H. Zitter, Corros. Sci. 4, 89 (1964)

2. H. H. Uhurg, Corrosion and Corrosion Control, John Wiley, New York (1963).

3. LANDOlt-Börnstein, Zahlenwerte und Funktionen, IV band. Technik 2 Teil, Springer, Berlin (1963).

4. C. J. SMItHells, Metals Reference Book. Butterworths, London (1962),

5. Th. HeumanN and H. BöHmer, Arch. EisenhüttWes. 31, 749 (1960).

6. R. STICKLER and A. VINCKLER, Corros. Sci. 3, 1 (1963).

7. R. Stickler and A. VINCKLer, Trans. Am. Soc. Metals 54, 362 (1961).

8. P. SCHAFMEISTER, Arch. EisenhüttWes. 10, 105 (1937).

9. W. Brauns and G. Pier, Stahl Eisen 75, 579 (1955).

10. J. Voeltzel and J. Plateau, C.r. hebd. Séanc. Acad. Sci., Paris 252, 2705 (1961). 
11. O. Kubaschewski and B. E. Hopkins, Oxidation of Metals and Alloys. Butterworths, London (1962).

12. J. BénARD, l'Oxydation des Métaux, Tome II. Gauthier-Villars, Paris (1964).

13. F. GABLER and W. WURz, Metall 13, 819 (1959).

14. L. E. SAMUels, Damaged surface layers, in The Surface Chemistry of Metals and Semiconductors (Edited by H. C. Gatos), John Wiley, New York (1960).

15. W. H. J. Vernon, F. WormWell and T. J. NuRSE, J. Iron Steel Inst. 11, 83 (1944)

16. U. R. Evans, The Corrosion and Oxidation of Metals. Arnold, London (1960).

17. J. Bardolle and J. Bénard, C.r. hebd. Séanc. Acad. Sci, . Paris 232, 231 (1951); 239, 706 (1954).

18. W. Jost, Diffusion. Academic Press, New York (1960).

19. H. S. Carslaw and J. C. Jaeger, Conduction of Heat in Solids. Clarendon Press, Oxford (1959).

\section{APPENDIX}

Diffusion during grain boundary precipitation ${ }^{18,19}$

The differential equations for the concentrations of $\mathrm{Cr}\left(\mathrm{C}_{1}\right)$ and $\mathrm{C}\left(\mathrm{C}_{2}\right)$ as a function of place and time are

$$
\frac{\partial^{2} C_{1}}{\partial x^{2}}-\frac{1 \partial C_{1}}{D_{1} \partial t}=0 \quad \frac{\partial^{2} C_{2}}{\partial x^{2}}-\frac{1 \partial C_{2}}{D_{2} \partial t}=0
$$

where $x$ is the coordinate perpendicular to the grain boundary which is assumed to be the plane $x=0 . D_{1}$ and $D_{2}$ are the diffusion coefficients of $\mathrm{Cr}$ and $\mathrm{C}$. The initial conditions are

$$
C_{1}=C_{1}^{0}, C_{2}=C_{2}^{0} \quad \text { all } x, t=0,
$$

where $C_{1}, C_{2}$ are the initial, uniform concentrations. The boundary conditions at infinite distance from the grain boundary are

$$
C_{1}=C_{1}^{0}, C_{2}=C_{2}^{0} \quad \text { all } t, x \rightarrow \infty .
$$

Because at the grain boundary we have the reaction (somewhat simplified)

$$
4 \mathrm{Cr}+\mathrm{C} \rightarrow \mathrm{Cr}_{4} \mathrm{C} \downarrow
$$

the first boundary condition at $x=0$ is

$$
D_{1} \frac{\partial C_{1}}{\partial x}=4 D_{2} \frac{\partial C_{2}}{\partial x} \text { all } t, x=0 \text {, }
$$

where it is implicitly assumed that the reaction is fast compared to the mass transport by diffusion. Assuming that the reaction is in equilibrium at every moment the second boundary condition is

$$
C_{1}^{4} \cdot C_{2}=K \text { all } t, x=0 .
$$

This, however, leads to a non-linear problem and therefore we take as an approximation at the boundary 


$$
C_{1}=0 \quad \text { all } t, x=0 .
$$

This means that it is assumed that the carbon content is not too low and that the diffusion of carbon is much faster than that of chromium.

The solution of this set of equations is found most easily using the Laplacetransformation. Introducing $u_{i}=\left(C_{i}^{0}-C_{i}\right) / C_{i}^{0}$ and writing $\vec{u}(p)$ for the Laplace transform of $u(t)$ as defined by

$$
\bar{u}(p)=\int_{0}^{\infty} u(t) e^{-p t} \mathrm{~d} t,
$$

this leads to the set of equations

$$
\frac{\mathrm{d}^{2} \bar{u}_{1}}{\mathrm{~d} x^{2}}-\frac{p}{D_{1}} \bar{u}_{1}=0, \frac{\mathrm{d}^{2} \bar{u}_{2}}{\mathrm{~d} x^{2}}-\frac{p}{D_{2}} \bar{u}_{2}=0 .
$$

The first of these has the general solution

$$
\bar{u}_{1}=A \exp \left[x \sqrt{ }\left(p / D_{1}\right)\right]+B \exp \left[-x \sqrt{ }\left(p / D_{1}\right)\right] .
$$

Using the transformed boundary conditions

$$
\bar{u}_{1}=\frac{1}{p} \text { at } x=0, \quad \bar{u}_{1}=0 \quad \text { at } x=\infty \text {, }
$$

this gives

$$
\bar{u}_{1}=\frac{1}{p} \exp \left[-x \sqrt{ }\left(p / D_{1}\right)\right]
$$

or after the inverse transformation

$$
u_{1}=\operatorname{erfc}\left[x / 2 \sqrt{ }\left(D_{1} t\right)\right]
$$

Using this in the boundary condition (4) gives as the new boundary condition for $u_{2}$ :

$$
\left(\frac{\partial u_{2}}{\partial x}\right)_{x=0}=-\frac{\mathcal{D}}{t^{1}} \text { with } \quad \mathcal{D}=\frac{D_{1}^{1} C_{1}}{4 D_{2} C_{2}^{0} \pi^{\frac{3}{3}}}
$$

and after transformation

$$
\left(\frac{\mathrm{d} \bar{u}_{2}}{\mathrm{~d} x}\right)_{x=0}=-\mathfrak{D} \sqrt{ }\left(\frac{\pi}{p}\right) \text { for } x=0 .
$$

The general solution of the second equation of $(7)$ is 


$$
\bar{u}_{2}=A \exp \left[x \sqrt{ }\left(p / D_{2}\right)\right]+B \exp \left[-x \sqrt{ }\left(p / D_{2}\right)\right] .
$$

Using the boundary conditions this gives

$$
\bar{u}_{2}=\frac{\mathfrak{D} \sqrt{ }\left(\pi D_{2}\right)}{p} \exp \left[-x \sqrt{ }\left(p / D_{2}\right)\right]
$$

and inverse transformation leads to

$$
u_{2}=\mathfrak{D} \sqrt{ }\left(\pi D_{2}\right) \operatorname{erfc}\left[x / 2 \sqrt{ }\left(D_{2} t\right)\right]
$$

For the concentrations themselves we obtain from (8) and (9)

$$
\begin{gathered}
\mathrm{Cr}: C_{1}=C_{1}^{0} \operatorname{erfc}\left[x / 2 \sqrt{ }\left(D_{1} t\right)\right] \\
\mathrm{C}: C_{2}=C_{2}\left\{1-\left(\frac{D_{1}}{D_{2}}\right)^{\frac{1}{2}} \frac{C_{1}^{0}}{C_{2}^{0}} \operatorname{erfc}\left[x / 2 \sqrt{ }\left(D_{2} t\right)\right]\right\}
\end{gathered}
$$

Because we must have always $C_{2} \geqslant 0$ the approximation is only possible when

$$
\left(\frac{D_{1}}{D_{2}}\right)^{\frac{1}{2}} \frac{C_{1}^{0}}{4 C_{2}^{0}} \leqslant 1
$$

From the literature ${ }^{2-5}$ we have at $T=923^{\circ} \mathrm{K}$

$$
D_{1}=2 \times 10^{-13} \mathrm{~cm}^{2} \mathrm{sec}^{-1}, \quad D_{2}=2 \times 10^{-8} \mathrm{~cm}^{2} \mathrm{sec}^{-1} .
$$

When the alloy contains $18 \% \mathrm{Cr}$ we have

$$
C_{1}^{0}=0.346 \text { mole }(100 \mathrm{~g})^{-1}
$$

and

$$
C_{2}^{0}=(\% \mathrm{C}) / 12 \text { mole }(100 \mathrm{~g})^{-1}
$$

This gives $\% \mathrm{C} \geqslant 0.346 \times \frac{12}{4} \times\left(\frac{2 \times 10^{-13}}{2 \times 10^{-9}}\right)^{\frac{1}{2}} \sim 0.015 \%$

which is much smaller than the usual carbon contents in these steels and this supports the applicability of the approximation inherent in the use of equation (6).

If we assume that at $12 \% \mathrm{Cr}$ the oxidation is noticeably faster (see Fig. 1) we have erfc $\left[x / 2 \sqrt{ }\left(D_{1} t\right)\right]=0.67$ which means $x / 2 \sqrt{ }\left(D_{1} t\right)=0.7$. After an annealing time of $20 \mathrm{~h}$ this gives for the expected width of the oxidized zone

$$
x=0.7 \times 2 \times \sqrt{ }\left(2 \times 10^{-13} \times 7.2 \times 10^{4}\right)=1.67 \times 10^{-4} \mathrm{~cm}=1.67 \mu
$$

